\title{
ARE RUSSIANS THE HIGHEST-PAID GOALIES IN THE NHL?
}

\author{
by
}

Paul M. Sommers

And

Douglas A. Raeder

March 2010

MIDDLEBURY COLLEGE ECONOMICS DISCUSSION PAPER NO. 10-09

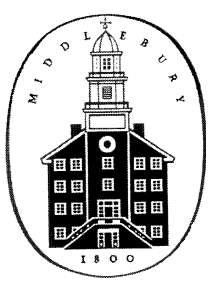

DEPARTMENT OF ECONOMICS

MIDDLEBURY COLLEGE

MIDDLEBURY, VERMONT 05753

http://www.middlebury.edu/ econ 
ARE RUSSIANS THE HIGHEST-PAID GOALIES IN THE NHL?

by

Douglas A. Raeder

Paul M. Sommers

Department of Economics

Middlebury College

Middlebury, Vermont 05753

JEL \#: J44, L83 


\section{ARE RUSSIANS THE HIGHEST-PAID GOALIES IN THE NHL?}

Twenty years after Glasnost, Russians in the National Hockey League (NHL) are now among the highest-paid goaltenders. Of the eighty-nine NHL goalies who played at least one game in the 2008-09 season, over 33 percent were born outside North America (and 4.6 percent of the total were from either Kazakhstan or Russia). A few years after Glasnost, there was evidence that Russian-born NHL players were underpaid (see Austin et al., IAER, 1998).

Salaries (in thousands of U.S. dollars) at the start of the 2008-09 season of all NHL goalies who played at least ten games in the 2007-08 season were regressed on goals against average (GAA) [equal to goals against multiplied by 60 and then divided by the goalie's minutes on the ice], the number of seasons (Seasons) played through 2007-08 (again, with a minimum of ten games played in each season), and the number of seasons squared (Seasons ${ }^{2}$ ). Ethnicity was initially broken down into four regional categories: Canadian, American, European, and Russian. Salary data are from www.nhlpa.com and players’ profiles are from www.nhl.com .

Goalies receive significantly higher salaries for a lower GAA $(p=.001)$ and experience, namely, the number of seasons played. [The coefficients on Seasons and Seasons ${ }^{2}$,

$1293.9(\mathrm{p}<.001)$ and $-60.44(p=.001)$, respectively, suggest $\partial$ Salary $/ \partial$ Seasons $=0$ when Seasons $=10.7$ or that compensation rises for the first eleven years in a goaltender's NHL career.] European-born goalies receive, on average, \$254 thousand less than their Russian counterparts ( $p=.825)$, Canadians $\$ 1.592$ million less $(p=.146)$, and Americans $\$ 2.676$ million less $(p=.034)$.

Ethnicity was then divided into a total of six regional categories. Western European goalies (from Sweden, Finland, Switzerland, France, and including one from South Africa) and Eastern European goalies (from the Czech Republic and Slovakia) receive \$181 thousand less 
( $p=.882)$ and $\$ 981$ thousand less $(p=.547)$ than their Russian counterparts, respectively. Canadian goalies from the predominantly French-speaking province of Quebec receive $\$ 1.481$ million less $(p=.208)$ and Canadian goalies from all other provinces receive $\$ 1.681$ million less $(p=.168)$ than their Russian counterparts. In this regression, Americans receive $\$ 2.691$ million less $(p=.038)$. 